\title{
Leaving Christianity
}

\author{
Teemu T. Mantsinen and Kati Tervo-Niemelä
}

\section{1 \\ Introduction}

The body of research on leaving Christianity is expansive, ranging from the historical and social scientific study of religion to practical theology and religious education. Just as the array of Christian churches and their nature is wide, so too is the nature of leaving Christianity varied. This chapter presents an overview of key aspects regarding leaving Christianity and its major trends and debates in history. Leaving Christianity is closely entwined with definitions of membership and being a Christian, changing social norms, and codes of conduct of church officials, but also broad historical socio-cultural changes.

\section{$2 \quad$ Key Terms}

Leaving Christianity has many connotations. From the outset, it is important to make a clear distinction between the terms heretic and apostate. Apostasy, deriving from the Greek word ¿ $\pi 0 \sigma \tau \alpha \sigma i \alpha$ (apostasia, a "refection" or "revolt"), refers to a formal disaffiliation or abandonment of religion. According to Christian faith "apostasy is a wilful falling away from, or rebellion against, Christian truth... [and] the rejection of Christ by one who has once been a Christian" (Muller 1985), and an apostate is thus a former Christian who rejects Christian faith. According to the Dictionary of Biblical Imagery (Ryken et al. 1998: 39), there are at least four different ways in which the word apostasy is used in the Bible. It is used in reference to (1) rebellion against (for example Joshua 22:22; 2 Chronicles 29:19), (2) turning away (for example Jeremiah 17:5-6; Judges 2:19), or (3) falling away from God and Christian faith, the latter being particularly evident in the New Testament (for example Matthew 7:24-27), and (4) adultery, which is one of the most common images of apostasy in the Old Testament (for example Jeremiah 2:1-3). Heretics, however, refer to people holding a deviant theological position or religious practice that is not accepted by the group and the leaders of the group to which the accused belongs. The word "heresy" came into wide use within Christianity through Irenaeus (130-202) and his second-century tract Contra Haereses (Against Heresies) in which he described, for example, the Gnostics' teachings as heretical (Frend 1984: 135-193). 
Furthermore, the understandings and connotations of leaving Christianity are strongly linked to belonging and membership of the church. According to Catholic understanding, once individuals become Catholics through baptism, they will remain Catholic unless they commit a sin grave enough to merit excommunication. They may become "lapsed" Roman Catholics if they do not fulfil the obligation to attend mass, although there is no record kept of who does and does not meet the terms of membership. Regarding the Church of England, there are at least three ways in which individuals can be said to belong to, and also leave, the Church. Firstly, all inhabitants in England belong to the Church of England unless they choose to belong to another denomination or religion or otherwise reject membership. Secondly, individuals may be said to forfeit Anglican Church membership if they do not receive communion at least three times a year, although no record of this is kept. Thirdly, those listed on the church's Electoral Roll can be regarded as members. In this case, leaving means letting one's name drop off the Electoral Roll, for example, by not attending mass or by missing the chance to fill out a certain form (Richter 2000: 21-22). The definition of membership is clearest in churches that have formal registered membership. This is common in countries where certain churches and religious groups have a right to levy taxes. In such cases, a member can be simply defined as a person who is a registered member of a church who pays church taxes. This is the case in many European countries (including Austria, Denmark, Finland, Germany, Iceland, Italy, Sweden and some parts of Switzerland), although there are also problems linked to this definition.

As the above suggests, it can be difficult to arrive at a clear definition of church leaving. For example, Richter and Francis (1998; Richter 2000: 24) used church attendance rather than membership when comparing church leaving in different denominations. They adopted Dean R. Hoge's definition of a church leaver as a person who has reduced his or her church attendance to less than six times a year (excluding Christmas, Easter, weddings and funerals) (Johnson et al. 1993; Richter and Francis 1998; Richter 2000: 34). However, in some countries church attendance has always been low. Therefore, the vast majority of registered church members would be categorised as church leavers according to this definition. Therefore, leaving Christianity needs to be defined separately in each case and in its historical context.

\section{$3 \quad$ Historical Developments}

Cases of leaving Christianity during the first century of Christianity are often dismissed and poorly documented. However, two issues are noteworthy in 
early Christianity. Firstly, deviant religious groups (such as the Gnostic movements, Marcionists and Montanists) were labelled heretics by the church authorities. Local church laws and canonical laws were often formed to dictate how to distinguish and manage those deemed as heretics (Van de Wiel 1991:

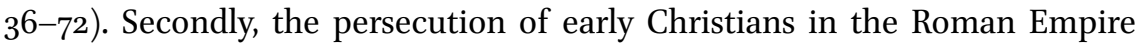
prompted a debate on how to deal with those who denied Christ. Some church leaders, such as Tertullian $\left(155^{-240}\right)$, considered fleeing persecution as apostasy. This caused some to fear apostasy when facing torture (Moss 2012: 108, 155). Later, Eusebius (275-339) favoured forgiving those who rejected Christ during persecution, in contrast with "heretical" Novatian (200-258), who denied reentry of relapsed believers to the church (Oropeza 2000: 8).

In medieval Christian Europe, the distinction between a heretic and an apostate was important also for legal reasons. However, the word apostate had multiple meanings in the Canon Law of the Catholic Church. It could refer to leaving the faith (apostasia a fide), or religious life, such as a monastic order (apostasia a religione). Thomas Aquinas (1225-1274) distinguished apostasy as abandonment of the faith (a fide), abandonment of clerical state ( $a b$ ordine), and abandonment of monastic life (a monachatus). Furthermore, the most common referent of apostate was fugitive, not someone leaving Christianity per se. Apostasy was often referred to as treason and rebellion, and punished by excommunication from society and the Church, and loss of wills and possessions (Riesner 1942; Oropeza 2000: 10-12).

A heretic in medieval Europe was foremost a person whose practice of Christianity was deviant; doctrinal issues were secondary or later constructions. A heretic had a chance to repent and return to the accepted practices of the Church. In the case of relapse, punishments were more severe. Apostasy of faith was seen, beyond heresy, as a total rejection of religion, meaning essentially the Church, or switching, for example, to Judaism. Witchcraft was depicted, for example, by Johannes Nider $(1380-1438)$ as a fundamentally heretical act of apostasy. In England, blasphemy, atheism and heresy were punishable by death between 1400-1677 (Kolpacoff Deane 2011: 219-220; Zagorin 2013; Välimäki 2016).

Following the Reformation, the term heretic was used to denote any kind of apostasy or switching religion, that is anyone who had a belief different to the dominant group (Hunter et al. 2005: 4). Moreover, what followed was a fragmentation of Western Christianity, enabling also internal movement, leaving institutions, and switching churches.

The Reformation enabled territorial rulers to choose the official religion of their domain in Western Europe. The Peace of Augsburg (1555) treaty and its statement cuius regio, eius religio, essentially meant that the religion 
of the ruler would be the religion of their subjects. In some areas, a coexistence of competing religions was accepted. The Transylvanian Diet's Edict of Torda is considered the first legal guarantee of religious freedom in Christian Europe, although with restrictions. In 1558 , the Edict declared free practice of both Catholicism and Lutheranism, although Calvinism was prohibited until 1564. In 1568, the freedom was extended: four denominations (Catholicism, Lutheranism, Calvinism and Unitarianism) were named as accepted denominations, while other denominations (such as the Orthodox Churches, Sabbatarians and Anabaptists) were tolerated churches, which meant that they had no legislative power, but they were not persecuted. In the Union of Utrecht (1579), freedom of conscience and private devotion and worship alongside the dominant religion was granted in the Netherlands. It allowed complete personal freedom of religion and is one of the first unlimited edicts of religious toleration. These earliest laws guaranteed people the personal right to practice their religion of choice, and to practice or not to practice religion as they wished.

Tolerance of atheism in Western Europe grew slowly through the enlightenment and modernisation. Apart from the short period of the French Revolution, change was slow and Christianity remained strong.John Locke (1632-1704) was one of the early developers of the thought of religious freedom, although he considered Roman Catholics unloyal in an Anglican England, and atheists a threat to national morale. National institutions slowly loosened their ties to Christian churches. The British court of law permitted the testimony of an atheist in 1869, and parliament accepted oaths without a Bible in 1886 (Zagorin 2013). In European colonies around the world, however, laws were not, or could not be, necessarily similarly applied. However, missionaries were constantly alerted by the possibility of natives relapsing into "uncivilised" lifestyles and syncretism (Barry et al. 2008).

The acceptance of religious freedom for individuals has varied across different Christian groups. In the Roman Catholic Church, the Second Vatican Council adopted the concept of religious freedom in its Dignitatis humanae (1965), but continued to oppose complete privatisation of religion and moral issues (Casanova 1994: 57). Many Protestant and Orthodox churches also have commitments to religious freedom.

In the twentieth century, the case of state-run atheism in Eastern Europe led to a massive decline in Christianity in those countries. For the study of leaving religion this poses challenges. It falls short of voluntary leaving, but merely dismissing it as a state-forced apostasy would not be sufficient. Organised secularisation was met with a counter-reaction after the fall of the Soviet Union, as many returned to the Orthodox Church or other religions. The politics of 
identity and objectification of religion led to the ethnicisation of religion, not national apostasy. For example, in Russia the Orthodox Church was a way to return to the assumed traditional Russian culture (Pelkmans 2009). A similar reaction was seen, for example, in Albania, which transformed from an atheist society to a society where 88 percent said they believed in God in 2011 (Endersen 2012).

However, state-run atheism or communist regimes did have a more longlasting effect in some countries and regions, such as former Czechoslovakia and East Germany. The consequences are very visible when comparing religious belonging, for example, in former East Germany compared to former West Germany. During the communist era the situation of Christianity was characterised by an enduring persecution of religious believers by the Communist government of East Germany. In 2010, while only 15\% of West Germans did not belong to a religious community, the figure among East Germans was $68 \%$ (Ilg et al. 2010: $5^{1-} 5^{2}$ ).

\section{Major Controversies and Significant Case Studies}

A controversial debate within Christianity has been the Muslim conquest of large parts of the Mediterranean world and the degree of freedom of conversion from Christianity to Islam. The story of forced mass conversions to Islam has prevailed, providing an explanation for why so many left Christianity. However, the conversion of entire populations was sometimes slow. For example, Egypt maintained a Christian majority for six centuries after the change of power, and Greece remained Orthodox under Ottoman rule (Hermansen 2014). In other cases, such as nineteenth-century southern Russia, Muslim culture and historical ethnicity were more appealing than colonial Christianity (Kefeli 2014). Arguably, preferential taxation in favour of Muslims and other practical matters make voluntary conversion debatable in many cases. In Muslim Spain (Al-Andalus, 711-1492), large-scale conversion to Islam happened only after major changes in government, legislation and culture. Umayyad emir Abd alRahman II (822-852) abandoned the egalitarian Arab style of governance in favour of the cultural sophistication of the Abbasid court in Baghdad, established new courts and state offices, and facilitated conditions for employment. This cultural revolution and the new professions, opportunities for livelihood, that it brought led to increasing assimilation into the new Islamic culture, and eventually to conversion to Islam. The more indigenous Muslims there were, the more indigenous Christians would convert (Coope 1993; Tieszen 2013, 21-44). 
An important theological debate of the Reformation was the soteriological question of being saved. The Calvinist-Arminian debate in the early seventeenth century was, among other issues, a dispute over whether, once saved, a Christian can lose their salvation and become an apostate. The debate had its precedent in a debate between Augustine of Hippo (354-430) and Pelagius $(360-420)$ over irresistible grace versus salvation through faith alone. John Calvin (1509-1564) went further than Augustine, proposing that God has chosen, that is predestined, people to either salvation or damnation by his sovereignty. Following this logic, there are no apostates since a person leaving Christianity was not chosen to be a Christian in the first place. Jacobus Arminius (1560-1609), however, excluded determinism from salvation. For him, salvation is conditional upon living a Christian life, and can be lost. Most Pentecostal and Evangelical groups follow Arminius' approach, expecting people both to choose and work for their salvation, although received by grace. Contrary to the Reformed views, Martin Luther (1483-1546) laid the foundation for the Protestant approach, which sees people as drawn to evil, and saveable only by God. This implies that salvation is solely the work of God, and apostasy is caused by the human nature to be drawn to evil (Demarest 1997; Calvin 2008; Luther 2008.) However, in Eastern Orthodoxy salvation is considered a free relationship, and therefore people have the capability to reject God (Carlton 2000).

Two important areas of controversy in Christianity in modern times have been liberalism and secularisation. Both have been affected by the enlightenment, and scientific, cultural and social developments in the Western world. The enlightenment was not simply an anti-religious programme, but, among other things, it was also a development towards a rational and intellectual approach to religion. However, the age of reason resulted in both secular humanism and religious liberalism. Many early philosophers of the enlightenment were born Christians but became critics or apostates of Christianity. For William Godwin (1756-1836), the key figure of modern anarchism and famous atheist of his time, moral and intellectual autonomy defined human beings. He was influenced by the rational Dissenters, who insisted that just as nature could be rationally explained, so, too, God had to be explained through human reasoning alone. The rational approach to religion and society was furthermore a criticism of the monopoly of power of the Church of England. Godwin further reasoned that man should not surrender to government or religion (Weston 2013).

The secularisation debate is closely related to the issue of state-church systems and their dismantling in Europe. However, while the former state churches, in particular, have lost members in Europe, Christianity in other parts of 
the world remains relatively attractive. In 1910 a third of the world's population were Christians (34.8\%), and in 2015 nearly a third (31.2\%), and the share is expected to remain largely unchanged until 2060 (31.8\%) (Pew 2011; 2017). However, the regional distribution of Christianity has changed and will change further: whereas in 1910 two-third (66\%) of the world's Christians were European, in 2015 the share was only a quarter $(24 \%)$ and is expected to decline to $14 \%$ by 2060 (Pew 2011; 2017). In contrast, the proportion of Christians in subSaharan Africa is growing (from $9 \%$ in 1910 to $26 \%$ in 2015 and expected to rise to $42 \%$ in 206o). However, it is important to point out that the major drivers behind this development are age distribution and fertility, not church leaving per se. In Europe, the Christian population is relatively old. (Pew 2011; 2017). However, Christian churches are also the group that is expected to experience most switching out worldwide: during a five-year period between 2015-2020 a total of 13 million people are expected to leave Christianity, most of them ending up religiously unaffiliated, particularly in Europe, North America, Australia and New Zealand (Pew 2017). Following this development, rather than disappearing, the former state churches (Europe) and mainline denominations (US) are losing their positions of power, and becoming more equal advocates in the religious, social, and political markets (Berger et al. 2008). These developments may be challenged by cases such as restoration of Church status in Poland, and possible reinterpretations of nationalism and Christian roots, as seen, for example, in Russia.

In Great Britain, the decline in Anglican attendance and membership rates and the increase in the number of people identifying as non-religious in national census has prompted debate in Britain and beyond on the role of religion and religious categorisation. People tend to define their relationship towards religion more independently than before, which poses the challenge of defining who is a Christian, compared to popular traditional definitions. Mainly in relation to the Christian (former) state churches, the current debate strives to grasp how some people believe without belonging or belong without believing, while others believe in belonging or neither believe nor belong (Davie 1990; Day 2011; Niemelä 2015; Brown and Woodhead 2016). Furthermore, religion and spirituality are also increasingly considered to be "fuzzy," something that does not fit into the categories of "religious" and "nonreligious" (Voas 2009) or "practicing" and "non-practicing" (Davie 2006). This means that religion is also increasingly regarded as something that cannot be interpreted merely by studying and analysing using traditional means and measures.

Another perspective on why many people, in this case in Sweden, are no longer identifying as Christians was given by David Thurfjell. He concluded that 
the case is not so much one of declining religiosity, but a process of narrowing the definition and meaning of being a Christian. According to Thurfell, the previous broad definition has been replaced with a stricter definition, favoured by revivalist groups and individuals. While the Lutheran Church traditionally considers all baptised Christians, the revivalists (including Pentecostals) expect a personal and active vocation of faith. This stricter understanding has alienated many cultural Christians away from Christianity and from the Church of Sweden (Thurfjell 2015).

Contemporary controversies often revolve around areas of sexuality and gender. The ordination of women to the ministry and changing attitudes and laws towards sexual minorities have caused a schism between liberals and conservatives, alienating people from both sides. These have been regarded among the biggest transformations in Christianity in the twentieth century (adoption of female ministry) and in the twenty-first century (increasing acceptance of same-sex relationships), and have also resulted in disaffiliation from Christianity. For example, in twentieth- and twenty-first-century Finland, the majority of the biggest peaks in church leaving from the former state Church have taken place alongside the debates regarding the ordination of women and the registration or marriage of same-sex couples. The debates over abortion and contraception have also contributed to church leaving (Byron and Zech 2012; Niemelä 2007).

Apostasy and falling away from Christian faith are mentioned in the Bible mainly in a few concentrated passages of the New Testament. Although there are similar passages in the Old Testament, these are usually dismissed by Christians as dated laws and social norms of ancient society dealing with conquering enemies and condemning their "false" gods. According to this understanding, Christianity begins with Jesus Christ and the old scriptures are applied in the light of the New Testament. According to the Bible, Jesus was aware that some of his followers would not last, but fall away. He compared his message and audience with seed and a farmer's field: if one's faith does not have "roots," the seed will not grow and will "fall away," but "those with a noble and good heart, who hear the word, retain it, and by persevering produce a crop" (Luke 8: 4-15).

The Apostolic letters have been used as the foundation for organising church life and social conduct. In the letters, leavers are depicted as being deceived by sin, and warnings of falling away are constant. In the Letter to the 
Hebrews $\left(3: 7^{-19} ; 6: 4-8 ; 10: 25^{-31}\right)$, the author warns of unbelief, which would deny a person of their salvation. Furthermore, they claim that "It is impossible for those who have once been enlightened [...] and who have fallen away, to be brought back to repentance." One proverb likens the apostate as a dog who returns to its vomit (2 Peter 2:17-22), illustrating how the Apostles viewed those who convert and leave.

The Apostolic letters were the first official formulations of group membership and norms of social conduct for a Christian community. One passage by Paul ( 1 Corinthians 5:1-5) has been later used as an example of excommunication. In it, Paul guides the Corinthians to expel a person committed of sexual immorality, for a limited time, so they could repent and possibly return: "So when you are assembled and I am with you in spirit, and the power of our Lord Jesus is present, hand this man over to Satan for the destruction of the flesh, so that his spirit may be saved on the day of the Lord."

The ultimate mark of apostasy in the Bible is the sin of blasphemy against the Holy Spirit. According to Matthew (12:31-32), Jesus said: "Anyone who speaks a word against the Son of Man [Jesus] will be forgiven, but anyone who speaks against the Holy Spirit will not be forgiven, either in this age or in the age to come." This passage is often linked with a story in Acts $(5: 1-10)$ in which a couple tried to lie to the apostles, only to fall dead: "Ananias, how is it that Satan has so filled your heart that you have lied to the Holy Spirit [-] You have not lied just to human beings but to God. When Ananias heard this, he fell down and died." These two Bible passages have been highly debated, but also used for social control, mainly in fundamentalist and other conservative groups outside mainline Christianity.

Another passage, often cited by Pentecostal and Evangelical groups, is "the great apostasy." Apostle Paul pleaded with the Thessalonians: "not to become easily unsettled or alarmed by the teaching [...] asserting that the day of the Lord has already come. Don't let anyone deceive you in any way, for that day will not come until the rebellion occurs and the man of lawlessness is revealed" (2 Thessalonians: 2). According to some Christians, this refers to a period in the end times when a large number of people will leave Christianity. The great apostasy has been identified, for instance, by various Pentecostals as, for example, the enlightenment and liberalism, the Roman Catholic Church, Islam, and the Soviet Union. Sometimes it is interpreted that the great apostasy will be followed by a final revival before the second coming of Christ (Anderson 2013: 165-170).

As previously noted, the persecution of the early Christian Churches prompted a debate on whether denying Christ under threat of death would be apostasy. Of the Apostolic Fathers and early writings, Shepherd of Hermes 
(Parables 26:6) says that it is impossible to be saved if a person intends to deny Christ, although there is the possibility to obtain later repentance for past sins. Tertullian saw apostasy as a form of mortal sin (De Poenitentia; De Idololatria; De Puditicia), criticising the Shepherd. However, Irenaeus (Against Heresies), while deeming apostates to be under God's punishment, stated that the apostasy was already judgement in itself, and God would not punish them directly at least immediately.

\section{$6 \quad$ Key Figures}

According to Augustinian theology, Christians cannot be certain of their salvation, despite of free will. Through sin and unbelief, one could lose salvation (Augustine 2010). Another major theologian, Thomas Aquinas, saw atheism as a crime against society, since society and the Church were more important than the individual. Along with many of his contemporaries, he equated apostasy with treason, punishable if not repented of (Aquinas 2002). The contemporary Catechism of the Catholic Church (2003) sees apostasy as a full rejection of Catholic doctrine, and as leaving the Church.

However, Karl Rahner (1904-1984), one of the most influential Roman Catholic theologians of the twentieth century, questions the possibility of absolute apostasy. According to him, apostasy would not only require denial of Christian propositions, but also a complete abandonment of any moral realities of those propositions. In a cultural environment in which Christianity has been an important source of influence, this is essentially impossible. Instead, Rahner considers those who live in Christian-influenced culture but reject Christian propositions to be heretics, Christians who have fallen short (Rahner 1966: 486-487). Pope Francis's (1936-) statement that God has redeemed everybody, including atheists (Catholic Online 2013), underlines this Catholic understanding of the perseverance of salvation.

The Protestant dispute on perseverance and assurance of salvation is highlighted in Lutheran theologian Francis Pieper's account on perseverance and apostasy:

What Scripture teaches on final perseverance may be summarized in these two statements: 1. He that perseveres in faith does so only through God's gracious preservation; the believer's perseverance is a work of divine grace and omnipotence. 2. He that falls away from faith does so through his own fault; the cause of apostasy in every case is rejection of God's Word and resistance to the operation of the Holy Spirit in the Word. 
This doctrine the Christian Church must maintain and defend on two fronts: against Calvinism and against synergism.

PIEPER 1968: 89

Although the Calvinist view could render predestination and election both ways, salvation and damnation, Karl Barth (1886-1968), a Reformed theologian, in his treatment of the question of predestination, reserved predestined judgement only to Jesus (Barth 1957). Methodists, Pentecostals, and other revivalist- and holiness-background Christians often follow in part the Arminian view on salvation, proposing that the Christ died for all, not only for the elected. However, Methodist leader Charles Wesley (1707-1788) preached that it is possible for a person to apostatise in such manner that it is "impossible to renew them again unto repentance" (Wesley 2001: 149-150). Wayne Grudem (b. 1948), a Reformed theologian widely respected in the PentecostalEvangelical field, combines these traditions by considering it more difficult to discern who is saved than who has become an apostate. In this he follows a common Revivalist Christian understanding that "faith" or religious conviction can be evaluated by its outcomes, by its good or bad "fruit." (Grudem 2000, 156-157.)

\section{7}

Conclusion

The history of Christianity is often seen in the light of expansion and power. However, when examined closely, stories of dissent and apostasy can be found throughout its history. Early Christianity saw the expulsion of heretics and deniers of Christ during Roman persecution. The Middle Ages witnessed the expansion of Islam and the gradual apostasy of large geographical parts of early Christendom. The Reformation and the Enlightenment brought ideas of secularism and liberalism, which resulted in a decline in Christianity in Europe. Other cases and individual developments continue to bring strain and dissent within Christianity, resulting in apostasy.

\section{References}

Anderson, A.H. 2013. To the Ends of the Earth: Pentecostalism and the Transformation of World Christianity. Oxford: Oxford University Press.

Augustine. 2010. On the Free Choice of the Will, On Grace and Free Choice, and Other Writings. Cambridge: Cambridge University Press.

Aquinas, T. 2002. On Law, Morality, and Politics. Indianapolis: Hackett Publishing co. 
Barry, A., Cruickshank, J., Brown-May, A., and Grimshaw, P. eds. 2008. Evangelists of Empire? Missionaries in Colonial History. Melbourne: Melbourne University eScholarship Research Centre.

Barth, K. 1957. Church Dogmatics, Volume 2, Part 2. Edinburgh: T\&T Clark.

Berger, P., Davie, G. and Fokas, E. 2008 Religious America, Secular Europe? A Theme and Variations. Farnham: Ashgate.

Brown A. and Woodhead, L. 2016. That was the Church, That Was: How the Church of England Lost the People of England. London: Bloomsbury.

Byron, W.J. and Zech, C. 2012. "Why They Left: Exit Interviews Shed Light on Empty Pews." America: The Jesuit Review, April 3oth, 2012. At https://www.americamaga zine.org/issue/5138/article/why-they-left. Accessed 26/6/2017.

Calvin, J. 2008 [1536]. Institutes of the Christian Religion. Peabody: Hendrickson.

Carlton, C. 2000. The Life: The Orthodox Doctrine of Salvation. Salisbury: Regina Orthodox Press.

Casanova, J. 1994. Public Religions in the Modern World. Chicago: University of Chicago Press.

Catechism of the Catholic Church. 2003. By Pope John Paul II, 2nd edition. New York: Doubleday.

Catholic Online 2013. "Pope Francis says atheists can do good and go to heaven too!" At https://www.catholic.org/news/hf/faith/story.php?id=51077. Accessed 13/5/2018.

Coope, J.A. 1993. "Religion and Cultural Conversion to Islam in Ninth-Century Umayyad Córdoba." Journal of World History. 4:1, 47-68.

Davie, G. 1990. "Believing without Belonging: Is This the Future of Religion in Britain?" Social Compass. 37:4, 455-469.

Davie, G. 2006. “Is Europe an Exceptional Case?” The Hedgehog Review. 8:1-2, 23-33.

Day, A. 2011. Believing in Belonging: Belief and Social Identity in the Modern World. Oxford: Oxford University Press.

Demarest, B. 1997. The Cross and Salvation: The Doctrine of Salvation. Wheaton: Crossway.

Dignitatis humanae. 1965. "Declaration on Religious Freedom Dignitatis Humanae on the Right of the Person and of Communities to Social and Civil Freedom in Matters Religious Promulgated by His Holiness Pope Paul VI on December 7, 1965." At http://www.vatican.va/archive/hist_councils/ii_vatican_council/documents/vat-ii _decl_19651207_dignitatis-humanae_en.html. Accessed 2/5/2017.

Endersen, C. 2012. Is the Albanian's Religion really "Albanianism": Religion and Nation According to Muslim and Christian Leaders in Albania. Wiesbaden: Harrasowitz Verlagen.

Frend, W.H.C. 1984. The Rise of Christianity. London: Darton, Longman \& Todd. 
Grudem, W. 2000. "Perseverance of the Saints: A Case Study from Hebrews 6:4-6 and Other Warning Passages in Hebrews." In T. R. Schriner, and B. A. Ware eds, Still Sovereign: Contemporary Perspectives on Election, Foreknowledge, and Grace. Grand Rapids: Baker Books, 133-182.

Hermansen, M. 2014. "Conversion to Islam in Theological and Historical Perspectives." In L.R. Rambo and C.E. Farhadian eds, The Oxford Handbook of Religious Conversion. Oxford: Oxford University Press, 632-666.

Hunter, I., Laursen, J.C. and Nederman, C.J. 2005. "Introduction." In I. Hunter, J.C. Laursen and C.J. Nederman eds, Heresy in Transition: Transforming Ideas of Heresy in Medieval and Early Modern Europe. Aldershot: Ashgate, 1-8.

Ilg, W., Schweitzer, F. and Simojoki, H. 2010. "Confirmation Work in Germany" In F. Schweitzer, W. Ilg, and H. Simojoki eds, Confirmation Work in Europe: Empirical Results, Experiences and Challenges. A Comparative Study from Seven Countries. München: Gütersloh, 51-52.

Johnson, B., Hoge, D.R. and Luidens, D.A. 1993. "Mainline Churches: The Real Reason for the Decline." First Things, 31: 13-18.

Kefeli, A.N. 2014. Becoming Muslim in Imperial Russia: Conversion, Apostasy, and Literacy. Ithaca: Cornell University Press.

Kolpacoff Deane, J. 2011. A History of Medieval Heresy and Inquisition. Lanham: Rowman \& Littlefield Publishers.

Luther, M. 2008 [1525]. The Bondage of the Will. Peabody: Hendrickson.

Moss, C.R. 2012. Ancient Christian Martyrdom. New Haven: Yale University Press.

Muller, R.A. 1985. Dictionary of Greek and Latin Theological Terms: Drawn Principally from Protestant Scholastic Theology. Grand Rapids; MI: Baker Book House.

Niemelä, K. 2007. "Alienated or Disappointed? Reasons for Leaving the Church in Finland." Nordic Journal of Religion and Society. 20:2, 195-216.

Niemelä, K. 2015 “'No Longer Believing in Belonging': A Longitudinal Study of Finnish Generation Y from Confirmation Experience to Church-Leaving." The Sociological Review. 62:2, 172-186.

Oropeza, B.J. 2000. Paul and Apostasy: Eschatology, Perseverance, and Falling Away in the Corinthian Congregation. Tübingen: Paul Siebeck.

Pelkmans, M. 20og. "Introduction: Post-Soviet Space and the Unexpected Turns of Religious Life." In M. Pelkmans ed., Conversion after Socialism: Disruptions, Modernisms and Technologies of Faith in the Former Soviet Union. New York: Berghahn Books, $1-16$.

Pew Research Center. 2011. "Global Christianity - A Report of the Size and Distribution of the Christian Population." At http://www.pewforum.org/2011/12/19/global -christianity-exec/. Accessed 23/01/2019. 
Pew Research Center. 2017. "The Changing Global Religious Landscape." At http:// www.pewforum.org/2017/04/05/the-changing-global-religious-landscape/. Accessed 11/02/2018.

Pieper, F. 1968. Christian Dogmatics Volume III. St Louis: Concordia.

Rahner, K. 1966. Theological Investigations, Volume V.: Later Writings. London: Darton, Longman \& Todd.

Richter, P. 2000. "Gone but not quite out of the frame: the distinctive problem of researching religious disaffiliation." In L.J. Francis and Y.J. Katz eds, Joining and Leaving Religion: Research Perspectives. Herefordshire: Gracewing, 21-31.

Richter, P. and Francis, L. 1998. Gone but not Forgotten: Church Leaving and Returning. London: Darton Longman \& Todd.

Riesner, A.J. 1942 Apostates and Fugitives from Religious Institutes: An Historical Conspectus and Commentary. Washington: The Catholic University of America Press.

Ryken, L. and Wilhoit, J.C. and Longman, T.III (eds.) 1998. Dictionary of Biblical Imagery. Westmont: InterVarsity Press.

Thurfjell, D. 2015. Det gudlösa folket: De postkristna svenskarna och religionen. Stockholm: Molin \& Sorgenfrei.

Tieszen, C.L. 2013. Christian Identity amid Islam in Medieval Spain. Leiden: Brill.

Välimäki, R. 2016. The Awakener of Sleeping Men:Inquisitor Petrus Zwicker, the Waldenses, and the Retheologisation of Heresy in Late Medieval Germany. Turku: University of Turku.

Van de Wiel, C. 1991. History of Canon Law. Louvain: Peeters Press.

Voas, D. 2009. "The Rise and Fall of Fuzzy Fidelity in Europe." European Sociological Review. 25:2, 155-168.

Wesley, C. 2001. The Sermons of Charles Wesley: A Critical Edition with Introduction and Notes. Oxford: University of Oxford Press.

Weston, R. 2013. "Radical Enlightenment and Antimodernism: The Apostasy of William Godwin (1756-1836)." Journal for the Study of Radicalism. 7:2, 1-30.

Zagorin, P. 2013. How the Idea of Religions Toleration Came to the West. Princeton: Princeton University Press. 